\title{
ERROR ANALYSIS ON INFORMATION AND TECHNOLOGY STUDENTS' SENTENCE WRITING ASSIGNMENTS
}

\author{
Rentauli Mariah Silalahi \\ Institut Teknologi Del, SUMUT, Indonesia \\ rentaulisilalahi@gmail.com
}

\begin{abstract}
Students' error analysis is very important for helping EFL teachers to develop their teaching materials, assessments and methods. However, it takes much time and effort from the teachers to do such an error analysis towards their students' language. This study seeks to identify the common errors made by 1 class of 28 freshmen students studying English in their first semester in an IT university. The data is collected from their writing assignments for eight consecutive weeks. The errors found were classified into 24 types and the top ten most common errors committed by the students were article, preposition, spelling, word choice, subject-verb agreement, auxiliary verb, plural form, verb form, capital letter, and meaningless sentences. The findings about the students' frequency of committing errors were, then, contrasted to their midterm test result and in order to find out the reasons behind the error recurrence; the students were given some questions to answer in a questionnaire format. Most of the students admitted that careless was the major reason for their errors and lack understanding came next. This study suggests EFL teachers to devote their time to continuously check the students' language by giving corrections so that the students can learn from their errors and stop committing the same errors.
\end{abstract}

Key Words: Error, error analysis, EFL, type of error, interlingual error, intralingual error

\begin{abstract}
ABSTRAK
Analisis terhadap kesalahan mahasiswa dalam Bahasa Inggris merupakan hal yang penting untuk guru Bahasa Inggris sebagai sumber untuk meningkatkan pengajarannya yang meliputi materi, penilaian dan metode. Proses analisis tersebut membutuhkan waktu yang lama dan usaha yang gigih dari si pengajar. Penelitian ini mengidentifikasi kesalahan-kesalahan umum yang terjadi pada kelas Bahasa Inggris tingkat 1 yang terdiri dari 28 mahasiswa baru di suatu perguruan tinggi yang bergerak dibidang IT (Informasi dan Teknologi). Data dikumpulkan dari tugas-tugas menulis mahasiswa selama delapan minggu berturut-turut. Dari data yang dikumpulkan, kesalahankesalahan umum mahasiswa dalam tugas menulisnya dikategorikan menjadi 24 tipe, dan yang menempati 10 tipe teratas kesalahan yang terjadi adalah pada penggunaan 'article', 'preposition', 'spelling', 'word choice', 'subject-verb agreement', 'auxiliary verb', 'plural form', 'verb form', 'capital letter', dan 'meaningless sentences'. Temuan ini kemudian dibandingkan dengan hasil ujian tengah semester mereka. Dan untuk mengetahui penyebab dari seringnya terjadi kesalahan tersebut, mahasiswa diminta untuk menjawab pertanyaan yang diberikan dalam bentuk kuesioner. Kebanyakan mahasiswa menyebutkan 2 alasan utama sebagai penyebab terjadinya kesalahan tersebut. Alasan yang pertama adalah karena kurang cermat dalam penggunaannya dan yang kedua adalah karena tidak mengerti cara penggunaannya. Dari hasil studi ini, diharapkan para guru Bahasa Inggris akan mengalokasikan waktu yang lebih banyak untuk memeriksa tulisan para pelajarnya dan memberikan koreksi/masukan sehingga mereka dapat belajar dari kesalahannya dan tidak mengulangi kesalahan yang sama.
\end{abstract}

Kata Kunci: Kesalahan, analisis kesalahan, pembelajar bahasa Inggris sebagai bahasa asing (EFL), tipe kesalahan, kesalahan interlingual, kesalahan intralingual 


\section{INTRODUCTION}

Writing is a medium of communication that represents language through the inscription of signs and symbols (Writing, 2014). Generally, there is one message delivered whenever someone is writing a text. The message can only be understandable if the writing comprises vocabulary, grammar and semantics (Writing, 2014). Unfortunately, for EFL (English as a Foreign Language) students, English is not innate but they have to do lots of efforts/practices to write something in English correctly and very often there are some errors in their written text. These errors could be very precious sources for teaching. Klassen (1994) did research that used the students' errors in writing as resources to teach the students. The research seemed to be successful that students most willingly learnt from their errors.

Limited knowledge of the grammatical rules and very rare occasions using the language in daily life conversation or interaction make EFL students find writing in English is more difficult than writing in their first language. Because of the limited knowledge, the EFL students often committed errors in their pieces of writings. Yet, many researchers have acknowledged that making errors in producing English in speaking and writing is a common issue for all students learning English whose mother tongue is other than English (Hussain, Hanif, Asif \& Rehman, 2013; Gustilo \& Magno, 2012; Yahya, Ishak, Zainal, Faghat \& Yahaya, 2012; Yang, 2010).

There are two kinds of errors in language learning i.e. interlingual errors (L1) and intrallingual errors (L2) (Bryant, 1984). Interlingual errors were errors resulted from one's mother tongue's intrusion; while intralingual errors were errors resulted from one's misinterpretation or overgeneralization of English grammar rules. Bryant (1984) found that the Japanese ESL students mostly made errors by the interference of their mother tongue or generally called L1 errors. While errors that resulted from L2 were only about the incorrect use of S-genitive and verb tense. However, the most dominant factor would not always be the same for every country. Silalahi (2013) found that L2 was the greatest cause for Indonesian students' errors in their spoken English while L1 contributed only very little amount.

There are some definitions of error analysis, yet all derived from James' definition (James, cited in Gustilo \& Magno, 2012; James, cited in Sarfraz, 2011, p. 31) who considered error analysis as "the study of linguistic ignorance, the investigation of what 
people do not know and how they attempt to cope with their ignorance." Dulay, Burt, and Krashen (1982, cited in Gustilo \& Magno, 2012, p. 98) strongly emphasized the definition of error analysis as "flawed side of learner speech or writing that deviates from selected norm of mature language performance". Gustilo and Magno (2012, p. 98) then simplified the definition of errors as "alterations of the rules of the accepted norm and are termed as surface errors which may be further classified as omission errors, addition errors, misinformation errors, wrong order, spelling errors, systems error, and the like".

Hussain et al. (2013) even made research on an error analysis to suggest changes in teaching curriculum in Pakistan. He argued that learners could commit errors in their language "due to memory lapses; physical states such as tiredness and psychological such as strong emotions" (p. 829).

Ellis (cited in Wang, 2008, p. 185) presented some steps in analyzing errors including "collection of a sample of learner language, identification of errors, description of errors, explanation of errors, and error evaluation." Knowing so many errors occurred in EFL students' language throughout the world encouraged the writer to do an error analysis towards her students' writings in order to find some ways to help them improve their skills and avoid committing the same errors. This study was carried out by implementing the steps introduced by Rod Ellis.

\section{METHOD}

This study presents descriptive data which identified and analyzed errors in EFL students' writings. This study is aimed at determining the types of errors made by 28 freshmen students majoring in IT in their English writing assignments which were collected and marked for 8 consecutive weeks during their first half semester studying at the university. The writing assignments were given every week after a completion of one topic about tenses. The writing assignments were to write sentences using the tense learnt before. The tenses taught to students were: Present Simple (Pr S), Present Continuous Tense (Pr C T), Past Simple (Ps S), Past Continuous Tense (Ps C T), Present Perfect (Pr Pf), Present Perfect Continuous Tense (Pr Pf C T), Simple Future $(S \mathrm{Ft})$, and Future Continuous Tense (Ft C T). During the writing assignments' collection time, the author made an experiment in which she collected the students' writing tasks and checked their language for grammatical errors and also gave mark. The author then made possible corrections for the students' errors by 
explicitly pointing the errors and published them for the students to read and learn from their errors.

The research was continued by collecting the students' midterm test result by the end of week 8 to be contrasted with the students' frequency of committing errors in the writing assignments to see the correlation between them. After getting the required data, it was analyzed and calculated in terms of percentage. The findings were then discussed and explained in terms of factors influencing the occurrence of errors in writing by giving questionnaires to the 28 students.

The analysis steps follow Ellis' (cited in Sarfraz, 2011), which consist of collection of samples of learner language (writing assignments), identification of errors, description of errors, and evaluation of errors. These steps can be found under the discussion on the types of errors.

\section{FINDINGS AND DISCUSSION}

\section{Types of Errors: Collection of Samples of Learner Writing Assignments}

In the half semester; 8 weeks, the students had learnt 8 Tenses: Present Simple, Present Continuous Tenses, Past Simple, Past Continuous Tense, Present Perfect, Present Perfect
Continuous Tense, Simple Future, and Past Future. The class meeting for every topic was held twice in a week for a total of 3 hours. Every time finishing the topic, the author, who was also the one teaching the students in the 8 weeks, asked the students to write sentences in English by using the formulas of the tenses learnt in positive, negative, and interrogative using a question word and auxiliary verb.

The students wrote at least 8 sentences and at most 22 sentences for the tense writing assignments. The students were only to write their own sentences by following the patterns that the teacher had given them in the classroom. The author then collected all of the students' sentences for analysis.

\section{Identification of Errors}

The 28 students collected their writing assignments every week for the class-teacher to mark and make some notes. The notes were about the students' errors and possible corrections to the errors. Usually, the students' errors were not about the wrong application of patterns learnt but other grammatical issues such as the improper use of article, preposition, and the like. It was not that hard to identify the errors as it was in the spoken language because the errors could explicitly be observed on the students' paper as Yang (2010) also 
claimed that error detection was easier with written text.

\section{Description and Evaluation of Errors}

From the data, the students' original sentences, there are a total of

Table 1. List of Students' Errors and Their Frequency of Occurrence

\begin{tabular}{|c|c|c|c|c|c|c|c|c|c|}
\hline No & Errors & $\operatorname{Pr} S$ & $\operatorname{Pr} C T$ & Ps $S$ & Ps C T & Pr Pf & $\operatorname{Pr} \operatorname{Pf} C T$ & S Ft & Ft C T \\
\hline 1 & article & 23 & 10 & 6 & 6 & 3 & 3 & 6 & 0 \\
\hline 2 & $\begin{array}{l}\text { sentence } \\
\text { structure }\end{array}$ & 1 & 1 & 0 & 0 & 0 & 0 & 0 & 0 \\
\hline 3 & $\begin{array}{l}\text { L1 } \\
\text { interference }\end{array}$ & 5 & 0 & 0 & 0 & 0 & 0 & 0 & 0 \\
\hline 4 & word choice & 22 & 9 & 4 & 0 & 1 & 0 & 0 & 0 \\
\hline 5 & verb form & 3 & 2 & 9 & 0 & 2 & 1 & 0 & 0 \\
\hline 6 & plural form & 12 & 1 & 0 & 2 & 3 & 0 & 0 & 0 \\
\hline 7 & phrasal verb & 1 & 0 & 0 & 0 & 0 & 0 & 0 & 0 \\
\hline 8 & Meaningless & 14 & 7 & 7 & 1 & 6 & 2 & 0 & 0 \\
\hline 9 & Spelling & 13 & 15 & 8 & 1 & 2 & 0 & 0 & 0 \\
\hline 10 & Preposition & 21 & 4 & 9 & 1 & 10 & 8 & 0 & 0 \\
\hline 11 & conjunction & 6 & 1 & 0 & 0 & 0 & 1 & 0 & 0 \\
\hline 12 & capital letter & 10 & 3 & 1 & 0 & 0 & 0 & 0 & 0 \\
\hline 13 & $\begin{array}{l}\text { subject-verb } \\
\text { agreement }\end{array}$ & 23 & 0 & 0 & 0 & 0 & 0 & 5 & 0 \\
\hline 14 & auxiliary verb & 7 & 3 & 0 & 1 & 2 & 6 & 8 & 0 \\
\hline 15 & $\begin{array}{l}\text { tense } \\
\text { agreement }\end{array}$ & 3 & 1 & 3 & 0 & 0 & 0 & 1 & 2 \\
\hline 16 & $\begin{array}{l}\text { uncountable } \\
\text { noun }\end{array}$ & 3 & 0 & 0 & 0 & 0 & 0 & 2 & 0 \\
\hline 17 & word order & 2 & 1 & 0 & 0 & 0 & 1 & 0 & 0 \\
\hline 18 & redundancy & 3 & 0 & 1 & 0 & 0 & 1 & 0 & 0 \\
\hline 19 & $\begin{array}{l}\text { missing } \\
\text { object/sbuject }\end{array}$ & 1 & 1 & 2 & 0 & 0 & 0 & 0 & 0 \\
\hline 20 & apostrophe & 1 & 0 & 2 & 0 & 0 & 0 & 0 & 0 \\
\hline 21 & missing verb & 1 & 0 & 0 & 1 & 0 & 0 & 1 & 0 \\
\hline 22 & adverb & 1 & 1 & 3 & 0 & 1 & 0 & 2 & 0 \\
\hline 23 & noun form & 1 & 0 & 0 & 0 & 0 & 0 & 0 & 0 \\
\hline \multirow[t]{2}{*}{24} & missing noun & 0 & 0 & 0 & 0 & 0 & 0 & 2 & 0 \\
\hline & Total & 177 & 60 & 55 & 13 & 30 & 23 & 27 & 2 \\
\hline
\end{tabular}

387 errors occurred during the writing assignments for all Tenses as shown on table 1. 
There are 24 numbers of common errors the students frequently made in their English writing including article, sentence structure, L1 interference, word choice, verb form, plural form, phrasal verb, spelling, preposition, conjunction, capital letter, subject-verb agreement, auxiliary verb, tense agreement, uncountable noun, word order, redundancy, missing object, apostrophe, missing verb, adverb, noun form, missing noun, and meaningless.

From Table 1, it can be seen that there had been decreases in numbers of errors regularly from the first to the fourth Tenses; from 177 to 13 errors only. However, the number increased for Present Perfect before it fell for Present Perfect Continuous and increased again for Simple Future before it fell drastically for Past Future to only 2 times errors. It was worth noted that it was a huge improvement that the students' errors in the second assignment were more than half less than theirs in the first assignment.

The shock therapy that the author applied to mark the students' writing assignments seemed to be successful. Through this, the students learned from their errors which were highlighted by the author with provided possible corrections. During the observation weeks, the author hardly made any effort to explain the students' errors in the classroom. She only explained the errors once after the announcement of the students' first assignment and barely on the next coming weeks. For the rest, the students did grasp the idea and made fewer errors in their later assignments.

Below are students' sample sentences with errors for every Tenses. The errors are indicated by an underline.

Table 2. Students' Sample Sentences

\begin{tabular}{|c|c|c|}
\hline Tenses & Sentence & Type of Error \\
\hline $\operatorname{Pr} S$ & $\begin{array}{l}\text { Dony change } \\
\text { clothes and eat. }\end{array}$ & $\begin{array}{l}\text { Subject-verb } \\
\text { agreement }\end{array}$ \\
\hline $\operatorname{PrCT}$ & $\begin{array}{l}\text { Who is drink a } \\
\text { cup of coffee? }\end{array}$ & Verb form \\
\hline Ps $S$ & $\begin{array}{lr}\text { I gone } & \text { to } \\
\text { church } & \text { in } \\
\text { Balige } & \text { last } \\
\text { Sunday. } & \end{array}$ & Verb form \\
\hline Ps C T & $\begin{array}{l}\text { Sandy looked } \\
\text { smart. He was } \\
\text { responsing to } \\
\text { all the lecture's } \\
\text { question. }\end{array}$ & Spelling \\
\hline Pr Pf & $\begin{array}{l}\text { I have red the } \\
\text { magazines for } \\
45 \text { minutes. }\end{array}$ & Spelling \\
\hline $\operatorname{Pr} \operatorname{Pf} C \mathrm{~T}$ & $\begin{array}{l}\text { She has been } \\
\text { thinking the }\end{array}$ & $\begin{array}{l}\text { Missing preposition } \\
\text { Missing article }\end{array}$ \\
\hline & $\begin{array}{l}\text { boy } \\
\text { hat. }\end{array}$ & \\
\hline $\mathrm{SFt}$ & $\begin{array}{l}\text { They will be } \\
\text { here next an }\end{array}$ & Adverb phrase \\
\hline & hour. & \\
\hline Ft C T & $\begin{array}{l}\text { I will get best } \\
\text { report last day } \\
\text { but I got sick. }\end{array}$ & $\begin{array}{l}\text { Auxiliary/verb form } \\
\text { Article } \\
\text { Noun form }\end{array}$ \\
\hline
\end{tabular}

The table above only presented one example of error for each tense. However from the data collected there were some findings that most errors that the students made did not automatically related to tenses forms but other grammatical issues or topics 
as already mentioned before (24 types of errors).

Below are students' sample sentences in which the author had made corrections to and were published on the academic site in which all students had access to and therefore they were able to read and learn from the teacher's correction to their sentences. The author did the same strategy in marking the students' writing assignment for 8 consecutive weeks. This method of correcting students' errors could initiate a comfortable learning environment for students because they did not only get scores but also comments from the teacher in the form of possible corrections. The errors are indicated by underline and possible corrections to the errors are indicated by italic.

Table 3. Students' Sample Sentences with Possible Corrections from the Teacher

\begin{tabular}{|c|c|c|}
\hline Student sentence & Possible correction & Type of Error \\
\hline $\begin{array}{l}\text { Sky cloudy. It is going to rain } \\
\text { today. }\end{array}$ & $\begin{array}{l}\text { The sky is cloudy. It is going to rain } \\
\text { today. }\end{array}$ & article \\
\hline $\begin{array}{l}\text { Who are they playing football in } \\
\text { the garden? }\end{array}$ & Who are playing football in the garden? & $\begin{array}{l}\text { sentence } \\
\text { structure }\end{array}$ \\
\hline How do they get high $\underline{\mathrm{IPK}} ?$ & $\begin{array}{l}\text { How do they get high GPA (Grade } \\
\text { Point Average)? }\end{array}$ & L1 interference \\
\hline I'll punch you if you come there. & I'll punch you if you go there. & word choice \\
\hline $\begin{array}{l}\text { Look at the windows. They are } \\
\text { going to broke. }\end{array}$ & $\begin{array}{l}\text { Look at the windows. They are going to } \\
\text { break. }\end{array}$ & verb form \\
\hline $\begin{array}{l}\text { The range of our mark are getting } \\
\text { worse. }\end{array}$ & $\begin{array}{l}\text { The range of our marks are getting } \\
\text { worse. }\end{array}$ & plural form \\
\hline $\begin{array}{l}I^{\prime} m \text { waiting my friend in entrance } \\
\text { hall just about } 15 \text { minutes. }\end{array}$ & $\begin{array}{l}I^{\prime} m \text { waiting for my friend in the entrance } \\
\text { hall for about } 15 \text { minutes. }\end{array}$ & $\begin{array}{l}\text { phrasal verb } \\
\text { (article, } \\
\text { preposition) }\end{array}$ \\
\hline $\begin{array}{l}\text { The moon only apears in the } \\
\text { night. }\end{array}$ & The moon only appears in the night. & spelling \\
\hline $\begin{array}{l}\text { Have he and his wife been living } \\
\text { their house for a long time? }\end{array}$ & $\begin{array}{l}\text { Have he and his wife been living in } \\
\text { their house for a long time? }\end{array}$ & preposition \\
\hline $\begin{array}{l}\text { I think Daniel will watch the } \\
\text { match of AC Milan and Barcelona } \\
\text { FC because he likes AC Milan. }\end{array}$ & $\begin{array}{l}\text { I think Daniel will watch the match } \\
\text { between AC Milan and Barcelona FC } \\
\text { because he likes AC Milan. }\end{array}$ & conjunction \\
\hline $\begin{array}{l}\text { My mother goes to the market } \\
\text { every tuesday. }\end{array}$ & $\begin{array}{l}\text { My mother goes to the market every } \\
\text { Tuesday. }\end{array}$ & capital letter \\
\hline $\begin{array}{l}\text { Andre hope you'll visit him in his } \\
\text { home one day. }\end{array}$ & $\begin{array}{l}\text { Andre hopes you'll visit him in his home } \\
\text { one day. }\end{array}$ & $\begin{array}{l}\text { subject-verb } \\
\text { agreement }\end{array}$ \\
\hline Where is she buy a pen? & Where does she buy a pen? & auxiliary verb \\
\hline $\begin{array}{l}\text { I'm thinking about you when I } \\
\text { saw Agnes on TV. }\end{array}$ & $\begin{array}{l}\text { I was thinking about you when I saw } \\
\text { Agnes on TV. }\end{array}$ & tense agreement \\
\hline I'm buying a food. & I'm buying some food. & $\begin{array}{l}\text { uncountable } \\
\text { noun }\end{array}$ \\
\hline
\end{tabular}




\begin{tabular}{|c|c|c|}
\hline Student sentence & Possible correction & Type of Error \\
\hline $\begin{array}{l}\text { I understand the language of } \\
\text { program computer now. }\end{array}$ & $\begin{array}{l}\text { I understand the language of computer } \\
\text { program now. }\end{array}$ & word order \\
\hline I promise to keep study hard. & I promise to $s t u d y$ hard. & redundancy \\
\hline Where have gotten this book? & Where have you gotten this book? & $\begin{array}{l}\text { missing } \\
\text { object/subject }\end{array}$ \\
\hline$\frac{\text { IT Del location }}{\text { Sitoluama, Laguboti. }}$ & $\begin{array}{l}\text { IT Del's location is on Sitoluama, } \\
\text { Laguboti. }\end{array}$ & $\begin{array}{l}\text { Apostrophe } \\
\text { (article) }\end{array}$ \\
\hline $\begin{array}{l}\text { We always breakfast at } 7 \text { o'clock } \\
\text { every morning. }\end{array}$ & $\begin{array}{l}\text { We always have breakfast at } 7 \text { o'clock } \\
\text { every morning. }\end{array}$ & missing verb \\
\hline Did she find the book tomorrow? & Did she find the book yesterday? & $\begin{array}{l}\text { adverb } \\
\text { noun form }\end{array}$ \\
\hline $\begin{array}{l}\text { She will give me a special present } \\
\text { for my sweet seventeenth. }\end{array}$ & $\begin{array}{l}\text { She will give me a special present for } \\
\text { my sweet seventeenth birthday. }\end{array}$ & missing noun \\
\hline $\begin{array}{l}\text { I was catching the first take off } \\
\text { place this morning. }\end{array}$ & - & meaningless \\
\hline
\end{tabular}

Unlike the findings found by Bryant (1984) in his research, this study found out that L1 interference was only a minor factor in causing errors in the students' writing. The L1 interference occurred only five times on the data analyzed. After collecting the questionnaire from the students, the author found out that the L1 intrusion occurred because of the students' limited vocabulary and they did not make any attempt to consult dictionary. Moreover, it happened because of the students' strong confidence that they had written the words correctly and the words were really English words while in fact, they're totally wrong.

For instance the student (student 8) who wrote "blender" instead of "blend" answered the question in the questionnaire saying "Because I think blender in English is blender, not blend." Her original sentence in the exercise was: "If you want to get a fresh juice, you must buy a fresh fruit and you must blender a fresh fruit soon."

The student used a noun instead of a verb for her sentence and that made her sentence incorrect. However, the student admitted her unfamiliarity with the verb form of "blend" for the noun "blender". The word "blender" was actually a common word in Bahasa Indonesia for it was an adopted word and had generally been used to refer to a tool people used to blend fruits and the like. In her sentence, student 8 actually produced some other errors in which she used article "a" for uncountable noun.

Looking at the frequency of errors' occurrence on table 1, it is worth reported that the top ten most common errors students produced in their writings from the highest to the lowest number of occurrence are as presented in table 4 . 
Table 4. The Top Ten Students' Most Common Errors

\begin{tabular}{clc}
\hline No & \multicolumn{1}{c}{ Type of Error } & $\begin{array}{c}\text { Number of } \\
\text { frequency }\end{array}$ \\
\hline 1 & Article & 57 \\
2 & Preposition & 53 \\
3 & Spelling & 39 \\
4 & Meaningless & 37 \\
5 & Word Choice & 36 \\
& Subject-verb & 28 \\
6 & agreement & \\
7 & Auxiliary verb & 27 \\
8 & Plural Form & 18 \\
9 & Verb form & 17 \\
10 & Capital letter & 14 \\
\hline
\end{tabular}

The biggest number of occurrence on "article" indicated that the topic was the most difficult grammatical issue for students and the table showed that "article" and "preposition" were the hardest topics for students to understand and apply in their sentences. With these findings, the teacher should have given some time to explain the topics to the students so that the students saw the corrections not only to their error sentences but also to understand the theory really well. However, the teacher did not allocate time for that but planned to make the two topics as part of the topics to be taught in the second semester for the students.

\section{Relation Between Students' Midterm \\ Test Result and Frequency \\ Committing Errors in Writing Assignments}

The students sat a midterm test by the end of week 8 . It meant that the test was held after the students had learnt all of the Tenses in the previous weeks. The midterm test was designed by the teacher who taught the students about the Tenses. The midterm test tested the students for all 8 Tenses they already learnt and no other than those. However, when observing the relation between the students' midterm test results to the frequency of errors students made in every writing assignment, a quite interesting finding indicating discrepancies is worth reported. The discrepancies are highlighted as follows:

Table 5. Students' Midterm Test Result and Their Frequency of Errors in Writing Assignment

\begin{tabular}{cccccccc}
\hline No & Student & $\begin{array}{c}\text { Number of } \\
\text { errors in writing } \\
\text { assignments for } \\
\text { Tenses }\end{array}$ & $\begin{array}{c}\text { Midterm test } \\
\text { score }\end{array}$ & No & Student & $\begin{array}{c}\text { Number of errors in } \\
\text { writing assignments } \\
\text { for Tenses }\end{array}$ & $\begin{array}{c}\text { Midterm } \\
\text { test score }\end{array}$ \\
\hline 1 & Student 1 & 4 & 40 & 15 & Student 15 & 3 & 39.16 \\
2 & Student 2 & 4 & 54.16 & 16 & Student 16 & 3 & 57.5 \\
3 & Student 3 & 4 & 51.66 & 17 & Student 17 & 2 & 67.5 \\
4 & Student 4 & 4 & 60.83 & 18 & Student 18 & 2 & 47.5 \\
5 & Student 5 & 3 & 53.33 & 19 & Student 19 & 2 & 64.16 \\
\hline
\end{tabular}




\begin{tabular}{llcccccc}
\hline No & Student & $\begin{array}{c}\text { Number of } \\
\text { errors in writing } \\
\text { assignments for } \\
\text { Tenses }\end{array}$ & $\begin{array}{c}\text { Midterm test } \\
\text { score }\end{array}$ & No & Student & $\begin{array}{c}\text { Number of errors in } \\
\text { writing assignments } \\
\text { for Tenses }\end{array}$ & $\begin{array}{c}\text { Midterm } \\
\text { test score }\end{array}$ \\
\hline 6 & Student 6 & 3 & 43.33 & 20 & Student 20 & 2 & 58.33 \\
7 & Student 7 & 3 & 53.33 & 21 & Student 21 & 2 & 37.5 \\
8 & Student 8 & 3 & 66.66 & 22 & Student 22 & 2 & 57.5 \\
9 & Student 9 & 3 & 55.83 & 23 & Student 23 & 2 & 45 \\
10 & Student 10 & 3 & 56.66 & 24 & Student 24 & 2 & 66.66 \\
11 & Student 11 & 3 & 42.5 & 25 & Student 25 & 1 & 58.33 \\
12 & Student 12 & 3 & 36.66 & 26 & Student 26 & 1 & 30.83 \\
13 & Student 13 & 3 & 49.16 & 27 & Student 27 & 1 & 49.16 \\
14 & Student 14 & 3 & 49.16 & 28 & Student 28 & 1 & 40.83 \\
\hline
\end{tabular}

The author made an assumption that making errors every time during the writing assignment for Tenses will certainly mean that the students most probably get low marks in the midterm test and vice versa. However, there are some interesting findings in which students who made errors on every assignment could get high scores in the midterm test as for students number 4 and 8 in which both got scores 60.83 and 66.66 consecutively. Likewise, an unusual finding occurred when 9 students who did well during the writing assignments in which they did errors only two or even once during the assignments collections ended up with low scores in their midterm test. These 9 students could only get scores ranging from 30.83 to 58.33 and only 3 students showed relevancy between their good achievement at writing assignments and their midterm test scores.
From the data found, the author could withdraw conclusion that making good progress in assignments did not necessarily ensure that the students would make good scores in the test but making good progress in assignments indicated that the students would make good preparation for the test. That was initially because the students did not know what the test would be like and the test was not all about writing sentences.

\section{Factors Influencing The Occurrence of Errors in Students' Writing Assignments}

Schachter (1974) did an analysis towards the learners' recurring errors in order to discover the reasons why the errors occur. However, for this study, in order to find concrete reasons for the error occurrence, the author collected the students' opinions by having them 
answer some questions through a questionnaire.

Through the questionnaire, the author discovered 14 general reasons for the students to create errors and there were two very outstanding reasons among them. As it was an open ended question, the students could give more than one reason for their answer. The author made a tally counting for the students' errors and found out that $29.16 \%$ of the students mentioned "being careless" was the major reasons of their errors and $20.83 \%$ of the students mentioned "lack of understanding towards the lessons" as a major cause of their errors. Below are the complete 15 reasons the students mentioned as the causes of their errors:

1. was careless

2. lack of understanding towards the lessons

3. was rushing in doing the exercises

4. was impatient

5. very often forgot the lessons

6. lack of vocabulary

7. forgot to use articles

8. lack of understanding in translation

9. forgot to use preposition

10. forgot to use auxiliary verbs

11. less practice

12. did not notice the instruction well

13. the questions were confusing

14. could not memorize formulas

When asked whether the teacher's corrections were useful or not, all of the students agreed upon one answer by saying 'yes'. The students gave some reasons to their positive response and $67.85 \%$ of their answers, in their own words, implied that the teachers' corrections were very useful in helping them to know their mistakes and helped them not to do the same mistakes in the following assignments.

Further, the questionnaire presented the students with a table consisted of 9 types of errors. They were asked to rank the errors from the most difficult topic to the least one. The topics were about article, preposition, spelling, word choice, subject-verb agreement, auxiliary verb, plural form, verb form, and capital letter. In order to analyze the data, the author calculated the average percentage of students' choices to each type of error and chose the biggest percentage for each type of error and the rank it referred to, to be reported. Most of the students chose "article" and "word choice" as the most difficult topics and prioritized them as number one, and "auxiliary verb" as the second most difficult topic. Both "subject-verb agreement" and "spelling" positioned on the third place with "preposition" came next. Interestingly, the majority students voted for capital letter as the least difficult one as $66.66 \%$ of them put number 9 on the column for capital 
letter. The data below will show clearer percentages among the topics.

Table 6. The Highest Percentage for Each Type of Error and Its Rank

\begin{tabular}{lcc}
\hline \multicolumn{1}{c}{ Topic } & $\begin{array}{c}\text { Percentage } \\
\text { (highest) }\end{array}$ & $\begin{array}{c}\text { Rank } \\
\text { chosen }\end{array}$ \\
\hline Article & $25.92 \%$ & 1 \\
Word-choice & $22.22 \%$ & 1 \\
Auxiliary verb & $29.62 \%$ & 2 \\
Spelling & $18.51 \%$ & 3 \\
Preposition & $22.22 \%$ & 4 \\
Subject-verb agreement & $22.22 \%$ & 5 \\
Verb form & $25.92 \%$ & 7 \\
Plural form & $22.22 \%$ & 8 \\
Capital letter & $66.66 \%$ & 9 \\
\hline
\end{tabular}

Having the data for which students thought to be the most difficult topics for them from the top 9 common errors students made on their writing assignments, the author then compared the ranks between those the author found out from the students' writing assignments and the students' responses to the questionnaire.

Table 7. The Types of Errors According to the Students' Questionnaire and Writing Assignments

\begin{tabular}{|c|c|c|c|}
\hline No & $\begin{array}{l}\text { Type of } \\
\text { Error }\end{array}$ & $\begin{array}{c}\text { Rank based } \\
\text { on students' } \\
\text { writing } \\
\text { assignment } \\
\end{array}$ & $\begin{array}{l}\text { Rank based on } \\
\text { students' } \\
\text { answer on } \\
\text { questionnaire } \\
\end{array}$ \\
\hline 1 & Article & 1 & 1 \\
\hline 2 & Preposition & 2 & 4 \\
\hline 3 & Spelling & 3 & 3 \\
\hline 5 & & 4 & 1 \\
\hline 6 & $\begin{array}{l}\text { Subject-verb } \\
\text { agreement }\end{array}$ & 5 & 5 \\
\hline 7 & $\begin{array}{l}\text { Auxiliary } \\
\text { verb }\end{array}$ & 6 & 2 \\
\hline 8 & Plural Form & 7 & 8 \\
\hline
\end{tabular}

\begin{tabular}{clcc}
\hline No & $\begin{array}{c}\text { Type of } \\
\text { Error }\end{array}$ & $\begin{array}{c}\text { Rank based } \\
\text { on students' } \\
\text { writing } \\
\text { assignment }\end{array}$ & $\begin{array}{c}\text { Rank based on } \\
\text { students' } \\
\text { answer on } \\
\text { questionnaire }\end{array}$ \\
\hline 9 & $\begin{array}{l}\text { Verb form } \\
\text { Capital }\end{array}$ & 9 & 7 \\
10 & letter & 9 & 9 \\
\hline
\end{tabular}

It is worth noted that although there were four similarities on the ranking between the findings from the students' writing assignments and the students' responses, there are some other significant discrepancies in which the students thought preposition was much less difficult topic than auxiliary verb, but in the real exercises, the students did most errors in terms of preposition than auxiliary verb. It would suggest that the teacher needed to take the topic "auxiliary verb" seriously as well and also taught the students more about preposition because it seemed that the students had little consciousness of their lacking understanding about preposition.

The final question in the questionnaire was to ask the students if the writing assignments were helpful in preparing them to sit the midterm test. 99\% of the students answered "yes" and mentioned some reasons to their positive attitude. However, quite unexpectedly, 1 of the students answered "no" to the question because she said she needed the kind of questions that would be potential to appear on the midterm test. 
After analyzing the students' answers to the last question, the author was interested to compare the midterm test class average score between this observed class and the other two classes who were not given correction errors for their writing assignments. From the data collected, the author found out that this class average score was much higher from one class but a bit lower from the other one. This observed class average score in the midterm test was 52.19, while the other two were 47.58 and 54.67 respectively. This would suggest that the class teacher needed to see further whether the class observed consisted of students who were majority weak in English as it was 2.48 lower than the other class who had no treatment for error correction to their writing assignment.

\section{CONCLUSION AND SUGGESTION}

Writing in English is not an easy task for EFL learners because it involves not only the logic in thinking to put the ideas in order and meaningful but also have enough vocabulary to use understand English sentence structures and tenses. When it comes into written texts, the teacher should encourage students to be aware of grammar or language accuracy.

From the errors on the students' writing assignments, the majority of the students had problems with articles and prepositions, though the students categorized auxiliary verb as more difficult than preposition. These findings were quite similar with research conducted in other schools or universities around the world whose students speak English as a second or foreign language.

Some conclusions could be worth noted and worth considered from this study as recommendation to the lecturers to improve their teaching practices to help the students learn better and in a long run to make the students as active learners and to enable them to use English fluently and grammatically correct. The pointed top ten errors students made should be considered as precious findings that the lecturer should put more emphasis on in teaching the current students and the future freshmen students. In order to avoid L1 interference, the lecturer should recommend the students to own and bring their dictionaries in English classes and use them as often as possible as it was found that the students hardly consult their dictionaries for unfamiliar words.

One big concern is that the lecturer should warn the students of their common error because there is possibility that the students did not know that they made errors. In addition, they might think that their 
works were correct as people mostly ignore the repeated errors, rather due to lack of linguistic competence. Poeple in generall are sometimes unable to identify them as errors and "this leads to the social acceptance of an error" (Sarfaz, 2011, p. 38). Therefore, continuous efforts from the lecturers are highly needed in order to spend time to check students' language and give correction and comment on their errors. In China, Wang (2008) claimed that teachers were given a primary responsibility to analyze students' errors because they were worth studying in order to help students learned more comfortably and without pressures of being marked wrong but being encouraged for the positive comments they got from their teachers.

Another suggestion to the lecturer is to give students more time to practice their lessons. Practice makes perfect and with more drills and directions, the students can master their lesson well. This effort will avoid students making errors as Sarfaz (2011, p. 37) claimed "in the absence of sufficient practice, the learners produce the language system which deviates from the system of TL."

\section{REFERENCES}

Bryant, William H. (1984). Typical Errors in English made by
Japanese ESL Students. JALT Journal, 6, 1-18.

Gustilo, L. \& Magno, C. (2012). Learners' Errors and their evaluation: The Case of Filipino ESL Writers. Philippine ESL Journal, 8, 96-113.

Hussain, Z., Hanif, M., Asif, S.I., and Rehman, A.U. (2013). An Error Analysis of L2 Writing at Higher Secondary Level in Multan, Pakistan. Interdisciplinary Journal of Contemporary Research in Business, 4(11), 828844.

Klassen, Johanna. (1994). Using student errors for teaching. Creative English teaching forum (134142).

Sarfaz, S. (2011). Error Analysis of the Written English Essays of Pakistani Undergraduate Students: A Case Study. Asian Transactions on Basic \& Applied Sciences (ATBAS), 1(3), 29-51.

Schachter, J. (1974). An error analysis in error analysis. Language Learning, 24, 205-214.

Silalahi, Rentauli M. (2013). Common Grammatical Errors in Spoken English of University Students in an IT University. Polyglot, 8, 16-29. 
Wang, Ping. (2008). Exploring Errors in Target Language Learning and Use: Practice meets Theory. English language teaching, 1(2), 182-187.

Yahya, A., Ishak, H.B.T., Zainal, Z., Faghat, L. J., Yahaya, N. (2012). Error Analysis of L2 Learners' Writings, a case study: proceedings of the 2012 International Conference on Language, Medias and Culture IPEDR, 33 (2012) (C) (2012) IACSIT Press, Singapore, pp. 114-118.
Yang, Wefen. (2010). A Tentative Analysis of Errors in Language Learning and Use. Journal of Language Teaching and Research, 1(3), 266-268.

Writing. (n.d.). In Wikipedia. Retrieved January 19，2014， from http://en.wikipedia.org/wiki /Writing. 
Rentauli Mariah Silalahi

166| IJEE, Vol. 1, No. 2, 2014 